\title{
БАЛАНС МІНЕРАЛЬНИХ РЕЧОВИН В ОРГАНІЗМІ КРОЛІВ НОВОЗЕЛАНДСЬКОЇ ПОРОДИ ПРИ ЗГОДОВУВАНІ ВІТАМІННО-МІНЕРАЛЬНОЇ ДОБАВКИ
}

\author{
Федорченко Максим Миколайович \\ асистент кафедри гігієні тварин та основ санітарії \\ Білоцерківський національний аграрний університет \\ ORCID: 0000-0002-5068-7037 \\ E-mail: cezarfam@ukr.net
}

Раціони кролів обов'язково необхідно балансувати за вмістом мінеральних елементів та вітамінів. Ці сполуки дуже важливі для організму кролів та приймають активну участь у метаболічних процесах. Від них залежить здоров'я тварин, розмноження, збереженість та продуктивність. Дуже важливе питання споживаності твариною мінеральних речовин, їх засвоюваності в організмі та виділення із нього. На засвоєння мінеральних елементів впливає забезпеченість, вміст їх у кормі, характер сполук, в складі яких ці елементи знаходяться, співвідношення між окремими мінеральними елементами та їх групами, вітаміннами, тощо. Автором теоретично обгрунтована та практично доведена ефективність застосування вітамінно-мінеральної добавки «Tеkro» для кролів Новозеландської породи. За кількісною характеристикою мінеральних елементів, потрібних для тварин, Кальцій займає перше місце і особливо потрібен в момент формування скелета. Введення до раціону кролів 3-ї і 4-ї дослідної груп вітамінно-мінеральної добавки «Теkго» показало підвищену засвоюваність Кальцію у їх організмі. Так за показником засвоєного Кальцію, кролі 3-ї та 4-ї дослідних груп пере-

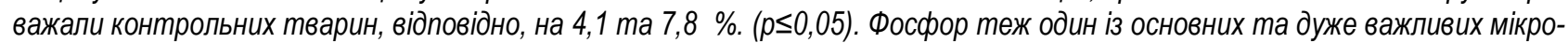
елементів і поряд з Кальцієм приймає участь в усіх обмінних процесах організму, входячи до складу різноманітних органічних сполук, протеїнів, фосфоліпідів, нуклеїнових кислот. Додаткове згодовування вітамінно-мінеральної добавки дослідним кролям забезпечило підвищення показника засвоєного Фосфору у організмі кролів 2-, 3- та 4-ї дослідних груп, за яким вони перевершували контрольних аналогів на 5,4%, 6,7 \% та 4,2%. Згодовування кролям Новозеландської породи вітамінно-мінеральної добавки «Tеkro» в кількості 3,5\% 3-й дослідній групі сприяло також підвищенню інтенсивності їх росту протягом 45 діб, забезпечило можливість кращої трансформації поживних речовин з корму в продукцію, що було підтверджено результатами аналізу манометричних показників та зафріксовано найбільший відсоток забійного виходу в 90 добовому віці, який становив на 8,89\% вище значення в порівнянні з показниками контрольної групи. Також у кролів 3-ї дослідної групи було зафріксовано у 90 добовому віці вищу активність глутатіонпероксидази у плазмі крові, що була $11,2 \%$ ( $5 \leq 0,05)$ вищою у порівнянні до кролів контрольної групи.

Ключові слова: кролики, вітамінно-мінеральна добавка, балансовий досвід, комбікорм, мінеральні речовини, кальчій, фоосфор, масометрічні показники.

DOI: https://doi.org/10.32845/bsnau.Ivst.2020.4.17

Постановка проблеми, аналіз останніх досліджень. Галуззю тваринництва, яка інтенсивно розвивається в Україні на сьогоднішній день $є$ кролівництво. Продуктами виробництва даної галузі є дієтичне м'ясо кролів, хутро, пух та шкіра тварин. Кролі $€$ рослиноїдними тваринами. Їхня система перетравлювання корму розвивається поступово і до трьохмісячного віку завершується процес сформованості травного каналу. Кролі володіють однокамерним шлунком. Характерною фізіологічною особливістю для даного виду тварин є їх споживання корму малими порціями. Дана властивість повязана з їх віковою, анатомічною та фізіологічною своєрідністю побудови травного каналу [5, 8, 9].

Кролі володіють значною кількістю переваг у порівнянні з іншими сільськогосподарськими тваринами $[6,13]$. Ці тварини відзначаються високою плодючістю. Організм кролиці може поєднувати період лактації та сукрільності. Це особливість, коли кролиці через 7-8 діб після народження кроленят вже здатні запліднюватися [5, 21]. Кролі відзначаються відсутньою сезонністю розмноження, володіють коротким періодом сукрільності та приналежною їм високою оплатою корму [5, 23].

Завдячуючи короткості сукрільного періоду, швидкій скоростиглості та росту молодняку в інтенсивному темпі - за 1 рік від 1 кролиці можливо отримати таку кількість м'яса, яка перевищує її власну масу більш як у 50 разів $[5,16,20]$. Процес перетравлення корму, в організмі кролів, потребує

насиченості раціонів тварин клітковиною, що забезпечує здешевлення вартості раціонів. Завдячуючи правильній організації годівлі та чіткому збалансуванню раціонів за всіма необхідними поживними речовинами в галузі кролівництва можливо досягти високої продуктивності тварин [18, 19].

В умовах можливостей сучасного ведення сільського господарства значні зусилля науковців і виробничників спрямовуються на розробку нових технологій, які були б ресурсозберігаючими та направленими на виробництво екологічно чистого м'яса і шкурок кролів, із запровадженням у годівлю тварин рецептів раціонів з використанням дешевих, нетрадиційних кормів, різних біологічно активних речовин, а також добавок вітамінно-мінерального складу [11, 12].

Актуальність. На даний момент виникла потреба у забезпеченні кролів кормовими високоякісними добавками у складі гранульованого повнораціонного комбікорму. Застосування неповноцінного комбікорму викликає незбалансованість у годівлі кролів, порушує відтворну здатність та обмін речовин в їх організмі, що підвищує витрати кормів на одиницю продукції тварин. В Україні за сучасних умов ринку сільськогосподарської продукції кролівничим господарствам пропонуються різні кормові добавки білково-вітамінномінерального складу [1, 10, 15, 22].

Метою роботи було вивчити перетравність мінера- 
льних речовин за додаткового

введення вітамінно-мінеральної добавки «Tekro» та дослідити вплив її на біохімічні показники антиоксидантної системи організму кролів Новозеландської породи.

Матеріали та методи дослідження. Дослідження проводили на кролях новозеландської породи, яких утримували у господарстві у виробничих умовах кролеферми ТОВ "Грегут". Клінічно здоровими були усі кролі. Годівля кролів забезпечувалась повнораціонними комбікормами належної якості. До корму та води доступ тварин був вільним. Для визначення та вивчення перетравності поживних речовин, а також балансу мінеральних речовин був проведений балансовий дослід за методиками, описаними у довідковій літературі $[3,4]$. Усіх дослідних тварин утримували у приміщенні за однакових умов. Досліди методом зважування проводили з точністю до 1 г. Для проведення дослідження показників балансового досліду з кожної групи відбирали 5 кролів, яких розміщували індивідуально у спеціально обладнаних клітках. Дослід проводили за методом груп у три періоди: підготовчий - 7 діб, попередній - 5 діб, обліковий - 6 діб. Аналіз кормів, калу, сечі проводили згідно з загальноприйнятими методиками зоохіманалізу [4]. Перед початком облікового періоду всі клітки мили, очищали від залишків корму, калу, сечі, пуху та дезінфікували. На кожній клітці закріпляли табличку, на якій записували номер групи, тварини і живу масу кроля. Збір калу і сечі проводили за допомогою спеціально виготовленого дна клітки, що нагадувало перевернуту до низу трапецію зі зрізаною вершиною. Зібраний кал очищали, зважували на вагах з точністю до 0,01 г і поміщали у банку з притертою кришкою. Як консервант використовували $10 \%$ розчин нітратної кислоти і тимол. Для дослідження хімічного складу калу наприкінці досліду з кожної банки брали середню пробу. Збір сечі проводили в скляні банки ємністю 500 мл 3 лійками, накритими фольтрувальною тканиною з крупними вічками. Для консервування сечі у банки добавляли 2-3 кристалики тимолу. Добову кількість сечі виливали у мірний циліндр для визначення об'єму, переливали в скляну банку і зберігали у холодильнику. Дослідження хімічного складу кормів, нез'їдених залишків, води, калу і сечі проводили за традиційними методиками зоотехнічного аналізу. На основі записів у журналі розраховували кількість з'їденого корму, виділеного калу і сечі. За даними хімічного аналізу визначали коефіцієнти перетравності поживних речовин корму і баланс мінеральних речовин.

Результати дослідження та обговорення. Раціони кролів крім поживних речовин також необхідно балансувати за вмістом мінеральних елементів, оскільки вони приймають активну участь у метаболічних процесах. На засвоєння мінеральних елементів впливає вміст їх у кормі, характер сполук, в складі яких ці елементи знаходяться, співвідношення між окремими мінеральними елементами, та їх групами, вітамінна забезпеченість тощо. Тому, про повноцінність мінерального живлення кролів можна стверджувати після дослідження обміну мінеральних елементів в організмі тварин.

Кальцій і Фосфор серед мінеральних елементів корму мають важливе значення в живленні тварин.

За кількісною характеристикою мінеральних елементів, що потрібно тваринам, Кальцій займає перше місце і особливо потрібен в момент формування скелета. Кальцій входить до складу кісток, зубів, бере участь в обмінних процесах, регулює роботу серця, м'язової і нервової систем, активує низку ферментів, впливає на засвоєння фосфору, цинку тощо [11].

У ході основного періоду досліду відмічено позитивний вплив різних рівнів згодовування вітамінно-мінеральної добавки на засвоєння Кальцію в організмі молодняка кролів (табл. 1).

Кролі всіх груп споживали майже однакову кількість гранульованого комбікорму, проте тварини 2-ї дослідної групи за кількістю Кальцію, що надійшов до організму на 8,3 \% поступалися показнику контрольної групи. Тварини 3-ї дослідної групи з кормом прийняли 1,794 г Кальцію , що на рівні контролю, але найбільше Кальцію надходило до організму тварин 4-ї дослідної групи і за цим показником вони переважали контрольних аналогів на 6,8 \%.

Таблиця 1

Баланс Кальцію в організмі піддослідних кролів, г, $\bar{X} \pm S_{\bar{X}}(\mathrm{n}=15)$

\begin{tabular}{|l|l|l|l|l|}
\hline \multirow{2}{*}{ Показник } & \multicolumn{3}{|c|}{ Група } \\
\cline { 2 - 5 } & \multicolumn{3}{|c|}{ Контрольна } & \multicolumn{3}{c|}{ Дослідна } \\
\cline { 2 - 5 } & 1 & 2 & $1,794 \pm 0,0247$ & $1,904 \pm 0,0197$ \\
\hline Прийнято 3 кормом & $1,783 \pm 0,0180$ & $1,653 \pm 0,0287$ & $1,010 \pm 0,0127$ & $1,091 \pm 0,0165^{*}$ \\
\hline Виділено з калом & $1,024 \pm 0,0119$ & $0,938 \pm 0,0120$ & $0,032 \pm 0,0033$ & $0,033 \pm 0,0023$ \\
\hline Виділено з сечею & $0,037 \pm 0,0035$ & $0,034 \pm 0,0025$ & $0,752 \pm 0,0152^{*}$ & $0,779 \pm 0,0073^{*}$ \\
\hline Засвоєно & $0,722 \pm 0,0100$ & $0,682 \pm 0,0191$ & $41,88 \pm 0,274^{*}$ & $40,95 \pm 0,436$ \\
\hline Засвоєно, \% від прийнятого & $40,48 \pm 0,204$ & $41,21 \pm 0,474$ & & \\
\hline
\end{tabular}

$-p \leq 0,05$

За показником засвоєного Кальцію, кролі 3-ї та 4-ї

Кількість Кальцію, що виділилася з калом у кролів 2-ї дослідної групи була меншою на 8,4 \% від контрольної групи. Тварини 3-ї дослідної групи, які спожили кальцію на рівні контролю з калом виділяли на 1,4 \% Кальцію менше. Кролі 4-ї дослідної групи з калом виділили Кальцію на 6,5% більше порівняно $з$ контролем.

У сечі кролів 2-ї дослідної групи Кальцію містилося на 8,1 \% менше, ніж у сечі контрольних аналогів. Кролі 3-ї та 4-ї дослідних груп також з сечею виділяли менше Кальцію, ніж кролі контрольної групи, відповідно на 13,5 та 10,8 \%. дослідних груп переважали контроль, відповідно, на 4,1 та 7,8 (p $\leq 0,05)$ \%. Тваринами 2-ї дослідної групи Кальцію організмом засвоєно було на 5,5 \% менше порівняно з аналогами контрольної групи.

За показником використання спожитого Кальцію тварини 2- та 3-ї дослідних груп перевищували контрольних аналогів, відповідно, на 0,73 та $1,4(P \leq 0,05) \%$. Тоді як кролі 4-ї дослідної групи за цим показником переважали контроль лише на $0,47 \%$. 
Отже, за кількістю засвоєного Кальцію кролі 3-ї дослідної групи, які споживали комбікорм з додаванням вітамінно-мінеральної добавки «Tekro»в кількості 3,5 \% переважали контрольних аналогів.

Фосфрор також один із основних мікроелементів і поряд з Кальцієм приймає участь в усіх обмінних процесах організму, входячи до складу різноманітних органічних сполук, протеїнів, фоссроліпідів, нуклеїнових кислот [11].

Додавання до комбікорму різної кількості кормових добавок вплинуло не тільки на обмін Кальцію в організмі кролів дослідних груп, а й на обмін Фосфрору (табл. 2).

Дані таблиці 2 свідчать, що тварини 2-, 3- та 4-ї дослідних груп споживали Фосфору у складі комбікорму дещо більше від кролів контрольної групи, відповідно, на 1,5\%; 1,9 i $1,0 \%$.
Основна частина Фосфору, що надходила в організм, виділялася з калом. Так, у калі кролів 2-, 3- та 4-ї дослідних груп містилося, відповідно, на 0,5\%; 0,3 та 0,2\% менше Фосфору порівняно з контролем.

Виділення Фоссрору з сечею у кролів 3-ї дослідної групи було на рівні показника контрольної групи. Тваринами 2- та 4-ї дослідних груп виділення елементу з сечею було вищим порівняно показником контрольної групи на 9 \%, хоча різниця не вірогідна.

Різниця спостерігалась і за кількістю засвоєного Фосфору. Зокрема, найкращим цей показник був у кролів 3-ї дослідної групи, за яким вони перевершували контрольних аналогів на 6,7\%. Тваринами 2- та 4-ї груп засвоєно було Фосфрору більше порівняно з контролем, відповідно, на $5,4 \%$ i $4,2 \%$.

Таблиця 2

Баланс Фосфору в організмі піддослідних кролів, мг, $\bar{X} \pm S_{\bar{X}}(\mathrm{n}=15)$

\begin{tabular}{|c|c|c|c|c|}
\hline \multirow{3}{*}{ Показник } & \multicolumn{4}{|c|}{ Група } \\
\hline & \multirow{2}{*}{$\begin{array}{c}\text { Контрольна } \\
1 \\
\end{array}$} & \multicolumn{3}{|c|}{ Дослідна } \\
\hline & & 2 & 3 & 4 \\
\hline Прийнято з кормом & $1,203 \pm 0,0012$ & $1,222 \pm 0,0212$ & $1,226 \pm 0,0169$ & $1,219 \pm 0,0126$ \\
\hline Виділено з калом & $0,823 \pm 0,0143$ & $0,819 \pm 0,0117$ & $0,821 \pm 0,0210$ & $0,822 \pm 0,0174$ \\
\hline Виділено з сечею & $0,011 \pm 0,0012$ & $0,012 \pm 0,0012$ & $0,011 \pm 0,0009$ & $0,012 \pm 0,0009$ \\
\hline Засвоєно & $0,370 \pm 0,0073$ & $0,390 \pm 0,0108$ & $0,395 \pm 0,0078$ & $0,386 \pm 67$ \\
\hline Засвоєно, \% від прийнятого & $30,75 \pm 0,684$ & $31,93 \pm 0,451$ & $32,20 \pm 0,885$ & $31,65 \pm 0,737$ \\
\hline
\end{tabular}

Про ефективність використання Фосфору, що містився в кормі, свідчить співвідношенням кількості засвоєного до прийнятого елемента. Найвищим $(32,2 \%)$ цей показник був у кролів 3-ї дослідної групи. Різниця між кролями цієї групи і контрольними аналогами становила 1,45 \%.
Досліджуючи забійні якості тушок кролів контрольної та дослідних груп, після нутрування нами були виділені такі частини: тушка, шкіра, голова, легені, серце, селезінка, печінка, нирки (табл. 3). На момент забою вік кролів всіх груп становив 90 діб.

Таблиця 3

Забійні якості кролів контрольної та дослідної групи, $\bar{X} \pm S_{\bar{X}}(\mathrm{n}=15)$

\begin{tabular}{|l|c|c|c|c|}
\hline Показник & $\begin{array}{c}1 \\
\text { Контрольна }\end{array}$ & $\begin{array}{c}2 \\
\text { Дослідна }\end{array}$ & $\begin{array}{c}3 \\
\text { Дослідна }\end{array}$ & $\begin{array}{c}4 \\
\text { Дослідна }\end{array}$ \\
\hline Передзабійна маса, г. & $2700 \pm 0,05$ & $2780 \pm 0,12$ & $2940 \pm 0,60$ & $2750 \pm 0,16$ \\
\hline тушка, г & $1502,6 \pm 54,34$ & $1800,4 \pm 47,56$ & $1850 \pm 47,56$ & $1720,4 \pm 47,56$ \\
\hline шкіра, г & $355,2 \pm 25,02$ & $372,1 \pm 28,10$ & $385,5 \pm 36,15$ & $362,3 \pm 32,10$ \\
\hline голова, г & $147,0 \pm 5,52$ & $148,5 \pm 3,49$ & $158,1 \pm 4,55$ & $150,6 \pm 4,18$ \\
\hline легені, г & $13,3 \pm 0,68$ & $14,7 \pm 0,70$ & $15,9 \pm 0,75$ & $15,0 \pm 0,62$ \\
\hline серце, г & $6,7 \pm 0,39$ & $7,0 \pm 0,32$ & $7,4 \pm 0,46$ & $6,9 \pm 0,42$ \\
\hline селезінка, г & $1,5 \pm 0,06$ & $1,7 \pm 0,09$ & $1,9 \pm 0,13$ & $1,7 \pm 0,10$ \\
\hline печінка, г & $77,1 \pm 2,19$ & $100,0 \pm 9,67$ & $109,0 \pm 9,67$ & $99,8 \pm 8,25$ \\
\hline нирки, г & $16,8 \pm 0,55$ & $18,0 \pm 0,11$ & $18,4 \pm 0,17$ & $17,9 \pm 0,09$ \\
\hline забійний вихід \% & $55,62 \pm 1,93$ & $64,74 \pm 1,56$ & $65,14 \pm 0,69$ & $62,54 \pm 1,60$ \\
\hline
\end{tabular}

Відомо, що печінка у кролів відносно маси тіла, порівняно з іншими сільськогосподарськими тваринами, $є$ найбільшим внутрішнім органом. У клітинах печінки проходять велика кількість метаболічних процесів біосинтезу та розчеплення протеїну, що забезпечує організм необхідними енергетичними та пластичними матеріалами. Під час дослідження печінки було встановлено, що найбільша печінка була у кролів 3-ї дослідної групи.

Було відмічено вищі показники маси тушки кролів дослідних груп порівняно з контролем. Дані показники можна пояснити позитивним впливом вітамінно-мінеральної добавки на обмінні процеси в організмі кролів усіх дослідних груп. Забійний вихід у кролів дослідних груп суттєво не змінювався та був найвищим у тварин 3-ї дослідної групи порівняно з контролем.

Середні показники відсоткового відношення складо- вих частин тушки кролів 3-ї дослідної групи були вищими: м'ясо - на 23,1\%, шкіра - на 8,5\%, печінка - на 41,4 \%, нирки - на 9,5\%, легені - на 19,5\%, серце - на 10,4\%, селезінка - на $26,7 \%$, голова - на $7,5 \%$, у порівнянні до показників контрольної групи.

Порівняльний аналіз результатів досліджень маси шкіри кролів дослідних груп показав вищі масометричні показники, ніж у тварин контрольної групи. Так, показники маси шкіри тварин 2-ї і 4-ї дослідних груп були вищими на 4,8 \% і 2,0 \% відповідно, порівняно з тваринами контрольної групи. Найбільшу масу шкіри фіксували у тварин 3-ї дослідної групи різниця із контролем становила 8,5\%.

У результаті проведення аналізу масометричних показників забійного виходу було встановлено, найбільший відсоток забійного виходу у кролів 3-ї дослідної групи порівняно $з$ іншими групами. Зокрема, показник забійного виходу 
кролів 3-ї дослідної групи був більшим на 2,6 \% у порівнянні 3 тваринами 4-ї дослідної групи, більшим на 0,4 \% у порівнянні з тваринами 2-ї дослідної групи, на 9,5% у порівнянні 3 тваринами контрольної групи.

Отже, одержані дані росту організму, масометричні показники тушки та внутрішніх органів кролів дослідних груп після забою можуть вказувати про позитивний вплив застосування вітамінно-мінеральної добавки на інтенсивність розвитку організму та окремих внутрішніх органів, що сприяє посиленому перебігу обмінних процесів і нарощуванню більшої маси тіла у тварин дослідних груп. Очевидно, що згодовування вітамінно-мінеральної добавки, кролям дослідних груп новозеландської породи впродовж 45 діб сприяло кращій трансфоормації поживних речовин корму в продукцію.

У кролів 3 дослідної групи у 90 добовому віці були зафріксовані найвищі показники маси тіла, які різнились на 8,89 \% у порівнянні з показниками контрольної групи.

Таким чином, застосування вітамінно-мінеральної добавки підвищує інтенсивність росту кролів новозеландської породи впродовж 45 діб і забезпечує можливість кращої трансформації поживних речовин із корму в продукцію тварин. Найкращий результат отримано у кролів 3-ї дослідної групи за дози 3,5 \%.

Ліпіди, в організмі тварин, виконують дуже важливі функції по накопиченню та забезпеченню енергії, $є$ структурними компонентами клітин, зокрема біологічних мембран. Окремі класи ліпідів представляють собою фізіологічно активні речовини (вітаміни, гормони) [7].

Загальний вміст ліпідів відображає активність анаболічних процесів та засвідчує їх використання в ролі джерела енергії в адаптивних змінах метаболізму та структурі компоненнтів клітин [17].

Аналіз наявності у середовищі плазми крові та печінці вмісту загальних ліпідів, у кролів контрольної та дослідної групи, засвідчує про періодичні зміни кількості даних сполук (табл. 4)

Проводячи порівняння, на 45 добу вирощування між групами кролів вмісту ліпідів у плазмі крові, було встановлено відсутність вірогідної різниці за даним показником між дослідними та контрольними тваринами. У послідуючому на 60 добу, у плазмі крові кролів дослідних груп в порівнянні до контрольних, була заффіксована тенденція по підвищенню вмісту загальних ліпідів.

Вміст загальних ліпідів в плазмі крові та печінці кролів $\bar{X} \pm S_{\bar{X}}(\mathrm{n}=5)$

\begin{tabular}{|c|c|c|c|c|}
\hline \multirow{3}{*}{ Вік, діб } & \multicolumn{4}{|c|}{ Загальні ліпіди } \\
\hline & \multicolumn{4}{|c|}{ Плазма, г/дм³ } \\
\hline & Контрольна 1 & Дослідна 2 & Дослідна 3 & Дослідна 4 \\
\hline 45 & $23,72 \pm 1,72$ & $24,53 \pm 1,50$ & $24,73 \pm 2,11$ & $25,23 \pm 2,01$ \\
\hline 60 & $16,23 \pm 3,02^{*}$ & $28,08 \pm 1,32$ & $28,18 \pm 1,97^{\wedge \wedge}$ & $29,02 \pm 1,59$ \\
\hline 75 & $17,01 \pm 2,42$ & $14,96 \pm 1,64$ & $14,91 \pm 0,84^{*}$ & $15,30 \pm 1,93$ \\
\hline 90 & $19,47 \pm 1,93$ & $13,01 \pm 1,36$ & $12,54 \pm 1,46^{\wedge}$ & $13,18 \pm 1,64$ \\
\hline \multicolumn{5}{|c|}{ Печінка, мг/г } \\
\hline 45 & $28,25 \pm 2,18$ & $28,60 \pm 1,97$ & $28,96 \pm 2,13$ & $28,68 \pm 2,06$ \\
\hline 60 & $33,82 \pm 2,71$ & $30,43 \pm 1,68$ & $29,78 \pm 2,93$ & $30,01 \pm 1,97$ \\
\hline 75 & $27,97 \pm 1,25$ & $28,00 \pm 1,24$ & $28,46 \pm 3,30$ & $28,54 \pm 1,35$ \\
\hline 90 & $27,81 \pm 1,47$ & $28,15 \pm 1,32$ & $27,64 \pm 1,13$ & $27,88 \pm 1,64$ \\
\hline \multicolumn{5}{|c|}{$\begin{array}{c}\text { ТБК-АП } \\
\text { Ппазма мкмопь }\end{array}$} \\
\hline \multicolumn{5}{|c|}{ Плазма, мкмоль/дм³ } \\
\hline 45 & $6,85 \pm 0,84$ & $6,68 \pm 0,44$ & $6,65 \pm 0,96$ & $6,70 \pm 0,32$ \\
\hline 60 & $5,82 \pm 0,38$ & $4,12 \pm 0,82$ & $4,24 \pm 0,56$ & $4,56 \pm 0,56$ \\
\hline 75 & $6,39 \pm 0,17$ & $6,05 \pm 0,30$ & $6,01 \pm 0,36^{*}$ & $6,10 \pm 0,63$ \\
\hline 90 & $6,70 \pm 1,07$ & $5,48 \pm 0,72$ & $5,50 \pm 0,86$ & $5,48 \pm 0,54$ \\
\hline \multicolumn{5}{|c|}{ Печінка, мкмоль/г } \\
\hline 45 & $0,17 \pm 0,02$ & $0,17 \pm 0,03$ & $0,17 \pm 0,01$ & $0,17 \pm 0,02$ \\
\hline 60 & $0,19 \pm 0,03$ & $0,12 \pm 0,06$ & $0,11 \pm 0,01^{* *}$ & $0,11 \pm 0,02^{*}$ \\
\hline 75 & $0,13 \pm 0,01$ & $0,11 \pm 0,02$ & $0,10 \pm 0,03$ & $0,10 \pm 0,05$ \\
\hline 90 & $0,12 \pm 0,01$ & $0,10 \pm 0,04$ & $0,09 \pm 0,01^{\wedge}$ & $0,09 \pm 0,03$ \\
\hline
\end{tabular}

Тканиноспецифрічним $€$ вміст загальних ліпідів, який від фізіолого-біохімічних особливостей кролів має залежність. Так з 60 по 90 добу в кролів контрольної групи в плазмі крові вміст загальних ліпідів характеризувався незначним підвищенням. Починаючи з 60 до 90 доби, у кролів дослідних груп у плазмі крові, вміст загальних ліпідів змінювався. Виявлені зміни можуть свідчить про вплив компонентів вітамінно-мінеральної добавки «Tekro».

Беручи до уваги вміст загальних ліпідів у кролів дослідної та контрольної групи, у різні періоди, у печінці за даним показником не було встановлено вірогідної різниці.

На початку дослідного періоду на 45 добу у кролів дослідної та контрольної групи вміст у плазмі крові ТБКактивних продуктів був найвищим. У тварин 3-ї дослідної групи на 60-ту добу вміст ТБК-активних продуктів характеризувався зміною даного показника, порівнюючи відносно тварин контрольної групи, на 38,1\%.

Самий факт зниження показника ТБК-активних продуктів відображає зменшення активності в організмі кролів процесі вільнорадикального утворення.

За визначення у печінці кролів контрольної групи вмісту ТБК-активних продуктів протягом всіх періодів дослідження була встановлена тенденція до зниження.

В ході проведених досліджень було зафіксовано на- 
ступний факт, що засвідчив позитивний вплив додаткового застосування вітамінно-мінеральної добавки «Tekro» від 3,0 до 4,0 \% до комбікорму кролів дослідних груп та характеризувався у зниженням у печінці тварин вмісту ТБК-активних продуктів з віком.

Таким чином, виявлені результати наших досліджень упродовж експериментального періоду, характеризуються переважаючим спаданням інтенсивності процесів ПОЛ та дають можливість стверджувати про достатню чутливість печінки дослідних тварин до впливу речовин вітамінномінеральної добавки «Tekro».

Одним із основних та найважливіших антиоксидантів глутатіонової системи $є$ глутатіон. Його функціональність в організмі тварин пов'язана із забезпеченням захисту плазматичних мембран клітин, що проявляється попередженням впливу на них руйнівної дії вільних радикалів. Відновлений глутатіон позитивно сприяє на функціональну активність ензимів та за нейтралізації активних форм Оксигену виступає як донор електронів [2].
За проведення вивчення на 45 добу у плазмі крові тварин дослідних груп вмісту відновленого глутатіону різниця між контрольною і дослідними групами була відсутня. На 60 добу вирощування кролів дослідні результати були встановлені аналогічні. На 75 добу було встановлено, що вміст відновленого глутатіону в організмах кролів 2 та 3 дослідних груп збільшувався $(p \leq 0,05)$ та $(p \leq 0,01)$ у середовищі плазми крові за дії 3,0 і 3,5\% вітамінно-мінеральної добавки «Tekro». На 90 добу вміст відновленого глутатіону вірогідно не різнився із контролем у тварин дослідних груп.

Суттєвої різниці за вмістом GSH у печінці між контрольною та дослідними групами у 45 добовому віці не зафіксовано. Беручи до уваги зміни результатів вмісту GSH було виявлено, що на 60 та 90 добу вирощування у тварин дослідних груп за дії кормової добавки «Tekro» у печінці концентрація відновленого глутатіону була найвища. Зокрема ці показники у кролів контрольної групи були менші ніж у тварин дослідних груп у 90 добовому віці

Таблиця 5

Вміст відновленого глутатіону і ГПО в плазмі крові та печінці кролів $\bar{X} \pm S_{\bar{X}}(\mathrm{n}=5)$

\begin{tabular}{|c|c|c|c|c|}
\hline \multirow{4}{*}{ Вік, діб } & \multicolumn{4}{|c|}{ Групи кролів } \\
\hline & \multicolumn{4}{|c|}{ GSH } \\
\hline & \multicolumn{4}{|c|}{ Плазма, ммоль/дм³ } \\
\hline & Контрольна 1 & Дослідна 2 & Дослідна 3 & Дослідна 4 \\
\hline 45 & $0,19 \pm 0,02$ & $0,20 \pm 0,06$ & $0,19 \pm 0,02$ & $0,19 \pm 0,04$ \\
\hline 60 & $0,20 \pm 0,03$ & $0,20 \pm 0,01$ & $0,20 \pm 0,02$ & $0,21 \pm 0,02$ \\
\hline 75 & $0,15 \pm 0,01$ & $0,28 \pm 0,02^{\wedge}$ & $0,33 \pm 0,04^{\star \wedge \Lambda}$ & $0,30 \pm 0,06$ \\
\hline 90 & $0,24 \pm 0,02^{* *}$ & $0,25 \pm 0,04$ & $0,25 \pm 0,01$ & $0,28 \pm 0,04$ \\
\hline \multicolumn{5}{|c|}{ Печінка, мкмоль/г } \\
\hline 45 & $0,22 \pm 0,03$ & $0,23 \pm 0,02$ & $0,22 \pm 0,02$ & $0,21 \pm 0,04$ \\
\hline 60 & $0,50 \pm 0,08^{* *}$ & $0,52 \pm 0,01^{* *}$ & $0,52 \pm 0,05^{\star \star \star}$ & $0,53 \pm 0,02^{* * *}$ \\
\hline 75 & $0,34 \pm 0,07$ & $0,22 \pm 0,09^{* *}$ & $0,23 \pm 0,02^{\star * \star}$ & $0,23 \pm 0,08^{* \star *}$ \\
\hline 90 & $0,32 \pm 0,02$ & $0,56 \pm 0,04^{* * \Lambda \Lambda}$ & $0,60 \pm 0,04^{* * * \wedge \wedge \wedge}$ & $0,59 \pm 0,05^{\star \wedge \wedge}$ \\
\hline \multicolumn{5}{|c|}{ ГПО } \\
\hline \multicolumn{5}{|c|}{ Плазма, мкмольххв/дм³ } \\
\hline 45 & $1,92 \pm 0,03$ & $1,90 \pm 0,04$ & $1,92 \pm 0,03$ & $1,91 \pm 0,02$ \\
\hline 60 & $1,94 \pm 0,02$ & $1,92 \pm 0,06$ & $1,99 \pm 0,02$ & $1,98 \pm 0,01$ \\
\hline 75 & $1,79 \pm 0,01^{\star *}$ & $1,80 \pm 0,02$ & $1,84 \pm 0,03^{\star *}$ & $1,84 \pm 0,02^{\star *}$ \\
\hline 90 & $1,69 \pm 0,04^{*}$ & $1,85 \pm 0,05$ & $1,88 \pm 0,02^{\wedge}$ & $1,90 \pm 0,03^{\wedge \wedge}$ \\
\hline \multicolumn{5}{|c|}{ Печінка, мкмольххв/г } \\
\hline 45 & $30,79 \pm 0,42$ & $30,48 \pm 0,40$ & $30,49 \pm 0,56$ & $30,36 \pm 0,39$ \\
\hline 60 & $31,18 \pm 0,29$ & $33,15 \pm 0,31^{* *}$ & $33,54 \pm 0,33^{\star \star \wedge \Lambda}$ & $32,84 \pm 0,50^{*}$ \\
\hline 75 & $31,61 \pm 0,52$ & $34,10 \pm 0,44^{\wedge \wedge}$ & $33,92 \pm 0,50^{\wedge \wedge}$ & $32,90 \pm 0,35$ \\
\hline 90 & $33,00 \pm 0,41^{*}$ & $34,98 \pm 0,50$ & $35,23 \pm 0,53^{\wedge}$ & $35,64 \pm 0,52^{\wedge \wedge}$ \\
\hline
\end{tabular}

У 3 дослідній групі кролів порівняно з показниками контрольної групи вміст відновленого глутатіону був найбільшим ( $p \leq 0,001)$.

У 45 добовому віці кролів було встановлено, що у плазмі крові тварин контрольної та дослідних груп активність глутатіонпероксидази суттєвої різниці не мала. У плазмі крові тварин найвища активність глутатіонпероксидази була зафіксована у 3 дослідній групі у 60-ти добовому віці. Такий фракт підвищення активності глутатіонпероксидази характеризувався тенденцією до зростання та був вищим у порівнянні до контрольної групи на 2,6 \%. Активність глутатіонпероксидази у 75 добовому віці в порівнянні до показників попереднього періоду 60 добового віку характеризувалась зниженням. У плазмі крові тварин контрольної групи було встановлено найменшу активність глутатіонпероксида- зи 1,69 мкМольххв/дм³ у 90 добовому віці. У тварин 3 дослідної групи у 90 добовому віці порівняно до кролів контрольної групи активність глутатіонпероксидази у плазмі крові була $(p \leq 0,05)$ вищою на $11,2 \%$.

У крові тварин активація ензиму може відбутись виключно за наявності достатньо великого рівня внутрішньоклітинного глутатіону (GSH), що забезпечує не лише виконання ролі субстрату реакції, а і діє як фактор, котрий необхідний для постійного відновлення селенольних груп розміщених у каталітичному центрі ензиму, які піддаються окисненню за глутатіонпероксидаційної реакції [2].

У період від 45 до 90 добового віку активності глутатіонпероксидази в печінці кролів характеризувалась динамікою змін, що відображались тенденцією до ступеневого 
підвищення.

Зокрема показники у кролів 3 дослідної групи характеризувались вірогідною різницею на 60-ту , 75-ту та 90-ту добу, яка була вищою на 7,4\% ( $\leq \leq 0,01), 7,3$ \% ( $p \leq 0,01)$ та $6,7 \%(p \leq 0,05)$ порівняно до показників контрольної групи відповідно.

Дані фракти можна пояснити дією складових компонентів вітамінно-мінеральної добавки «Tekro», які містять Селен у своєму складі, що забезпечує активацію ензиму глутатіонпероксидази [14].

У підтримці пероксидного окиснення ліпідів на фрізіологічному рівні у клітинах провідну роль забезпечують ензими антиоксидантного захисту.
За проведення лабораторних досліджень були встановлені позитивні значення, які відображають у плазмі крові і тканинах печінки кролів 3 дослідної групи вплив оптимальної кількості вітамінів і мікроелементів на функціональну активність ензимів антиоксидантного захисту (табл.3.23).

Вплив на різні фізіолого-біохімічні процеси, у складі ензимів, проявляють сульфогідрильні групи, які здатні захищати клітини від руйнуючої дії токсичного радикалу, що утворюється в наслідок розщеплення молекули $\mathrm{H}_{2} \mathrm{O}_{2}$ [2].

У плазмі крові кролів контрольної групи у дослідний період з 45 до 75 дня було зафіксовано зниження вмісту SHгруп. Дані зниження вмісту SH-груп засвідчували підвищення концентрації вільних радикалів (табл. 6).

Таблиця 6

Вміст загальних, білкових і вільних SH-груп в плазмі крові та печінці кролів $\bar{X} \pm S_{\bar{X}}(\mathrm{n}=5)$

\begin{tabular}{|c|c|c|c|c|}
\hline \multirow{4}{*}{ Вік, діб } & \multicolumn{4}{|c|}{ Групи кролів } \\
\hline & \multicolumn{4}{|c|}{ SH-групи загальні } \\
\hline & \multicolumn{4}{|c|}{ Плазма, мкмоль/дм³ } \\
\hline & Контрольна 1 & Дослідна 2 & Дослідна 3 & Дослідна 4 \\
\hline 45 & $399,60 \pm 8,98$ & $375,57 \pm 38,26$ & $376,44 \pm 13,42$ & $380,34 \pm 12,52$ \\
\hline 60 & $374,04 \pm 19,84$ & $350,43 \pm 22,65$ & $342,48 \pm 29,31$ & $345,51 \pm 24,13$ \\
\hline 75 & $316,68 \pm 16,14^{*}$ & $450,67 \pm 24,76^{* \wedge}$ & $454,92 \pm 18,44^{* \star \wedge \wedge}$ & $455,28 \pm 16,70^{\star \star \wedge \Lambda}$ \\
\hline 90 & $412,80 \pm 27,44$ & $516,58 \pm 12,43$ & $516,48 \pm 10,79^{\wedge \wedge}$ & $518,84 \pm 14,13$ \\
\hline \multicolumn{5}{|c|}{ Печінка, мкмоль/г } \\
\hline 45 & $352,80 \pm 21,79$ & $375,52 \pm 20,11$ & $385,68 \pm 19,72$ & $388,94 \pm 13,70$ \\
\hline 60 & $343,44 \pm 32,61$ & $332,38 \pm 12,68$ & $318,48 \pm 15,73^{*}$ & $320,60 \pm 19,27$ \\
\hline 75 & $421,68 \pm 10,24$ & $426,19 \pm 15,38$ & $429,84 \pm 13,41^{* *}$ & $432,46 \pm 15,10$ \\
\hline 90 & $394,32 \pm 25,81$ & $392,93 \pm 22,13$ & $398,40 \pm 26,54$ & $398,59 \pm 19,54$ \\
\hline \multicolumn{5}{|c|}{ SH-групи вільні } \\
\hline \multicolumn{5}{|c|}{ Плазма, мкмоль/дм³ } \\
\hline 45 & $63,1 \pm 4,12$ & $59,3 \pm 4,09$ & $61,2 \pm 3,12$ & $57,2 \pm 4,12$ \\
\hline 60 & $60,0 \pm 3,15$ & $60,4 \pm 5,12$ & $58,1 \pm 4,56$ & $59,3 \pm 6,15$ \\
\hline 75 & $58,6 \pm 2,99$ & $88,5 \pm 4,19^{\wedge \wedge}$ & $91,3 \pm 4,17^{\wedge \wedge}$ & $90,2 \pm 4,12^{\wedge \wedge}$ \\
\hline 90 & $70,2 \pm 5,16$ & $93,2 \pm 6,14^{\wedge}$ & $95,7 \pm 4,21^{\wedge \wedge}$ & $98,6 \pm 6,13^{\wedge}$ \\
\hline \multicolumn{5}{|c|}{ Печінка, мкмоль/г } \\
\hline 45 & $74,04 \pm 3,04$ & $74,66 \pm 2,30$ & $75,60 \pm 2,38$ & $75,86 \pm 2,55$ \\
\hline 60 & $74,88 \pm 2,21$ & $71,78 \pm 2,25$ & $71,88 \pm 1,33$ & $72,90 \pm 1,92$ \\
\hline 75 & $84,36 \pm 2,27^{*}$ & $82,92 \pm 1,16^{*}$ & $82,32 \pm 1,28^{\star *}$ & $84,23 \pm 1,58^{* *}$ \\
\hline 90 & $72,72 \pm 3,00$ & $81,73 \pm 2,20$ & $77,76 \pm 1,01$ & $83,27 \pm 2,06$ \\
\hline \multicolumn{5}{|c|}{ SH-групи білкові } \\
\hline \multicolumn{5}{|c|}{ Плазма, мкмоль/дм³ } \\
\hline 45 & $336,5 \pm 16,32$ & $316,3 \pm 14,75$ & $315,2 \pm 10,86$ & $323,14 \pm 10,53$ \\
\hline 60 & $314,0 \pm 20,13$ & $290,1 \pm 17,93$ & $284,4 \pm 19,56$ & $286,2 \pm 11,98$ \\
\hline 75 & $258,10 \pm 8,19$ & $362,17 \pm 12,84^{\wedge \wedge}$ & $363,6 \pm 16,03^{\wedge \wedge}$ & $365,1 \pm 20,21^{\wedge \wedge}$ \\
\hline 90 & $342,6 \pm 15,42$ & $423,4 \pm 19,86^{\wedge}$ & $426,8 \pm 15,39^{\wedge}$ & $420,2 \pm 28,61^{\wedge}$ \\
\hline \multicolumn{5}{|c|}{ SH-групи білкові } \\
\hline \multicolumn{5}{|c|}{ Печінка, мкмоль/г } \\
\hline 45 & $278,81 \pm 21,17$ & $300,9 \pm 17,96$ & $310,11 \pm 19,83$ & $313,1 \pm 9,76$ \\
\hline 60 & $268,61 \pm 30,50$ & $260,6 \pm 15,39$ & $235,81 \pm 16,03$ & $277,7 \pm 12,56$ \\
\hline 75 & $337,31 \pm 8,26$ & $343,3 \pm 21,13$ & $347,51 \pm 13,65$ & $348,1 \pm 10,16$ \\
\hline 90 & $321,60 \pm 17,48$ & $311,2 \pm 14,36$ & $320,60 \pm 17,95$ & $315,3 \pm 17,19$ \\
\hline
\end{tabular}

Підчас дослідження у плазмі крові вмісту загальних тіолових груп у 45 та 60 добових кролів, між групами була встановлена відсутність вірогідної різниці (табл. 3.24). У свою чергу у 75 добових кролів було визначено, що у плазмі крові у контрольній групі тварин відбулося на 15,3\%

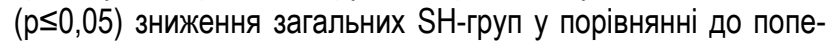
реднього 60 добового періоду.

Окрім цього у дослідних групах кролів було зафіксовано обернену залежність. У тварин 3 дослідної групи вміст загальних SH-груп знаходився на на 20,8 \% (p $\leq 0,01)$ вищому рівні ніж у 60 добовому віці. На 75 добу, у цей же самий період було встановлено у плазмі крові кролів 2, 3 та 4 дослідної групи підвищення кількості загальних тіолових груп відносно контролної групи на 42,2 \%, 43,6 та 43,9 \% відповідно. Надалі у 90 добовому віці у плазмі крові 3 дослідної групи кролів також було встановлено вірогідне підвищення вмісту загальних SH-груп.

Проводячи дослідження у печінці кролів контрольної 
та дослідних груп на 45 добу, вірогідних відхилень у показниках вмісту загальних тіолових груп не було виявлено. У печінці тварин 3 та 4 дослідної групи підвищення вмісту загальних SH-груп мало характер тенденції.

Було зафріксовано у печінці кролів 3 дослідної групи на 60 добу вірогідне зниження загальних SH-груп порівняно до показників отриманих у 45 добовому віці.

Подальші дослідження на 75 добу засвідчили зростання у печінці кролів вмісту загальних SH-груп відносно 60 доби. Найвища різниця була зафріксована у кролів $3(p \leq 0,01)$ та 4 дослідної групи.

У загальному було експериментально доведено, що застосування у кількості 3,5 та 4,0% вітамінно-мінеральної добавки у складі комбікормів викликає на 75 добу у печінці кролів 3 та 4 дослідної групи тендецію щодо підвищення вмісту загальних SH-груп.

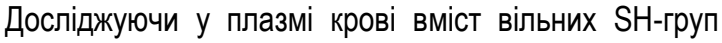
було встановлено, підвищення даного показника з віком у кролів контрольної і дослідних груп. Окрім цього, на 75 добу було виявлене вірогідне підвищення вмісту вільних SH-груп у плазмі крові 2, 3 та 4 дослідних груп кролів в результаті впливу на їх організм різних доз вітамінно-мінеральної добавки «Tekro».

У плазмі крові кролів 2, 3 та 4 дослідної групи на 90 добу було виявлено підвищений на $32,7 \%$ (P $\leq 0,05) ; 36,3 \%$ $(\mathrm{P} \leq 0,01)$ та $40,4 \%(\mathrm{p} \leq 0,05)$ вміст вільних SH-груп відносно контролю.

У 75 добовому віці кролів було встановлено у печінці тварин із контрольної та дослідних груп найвищий вміст вільних тіолових груп. По періодах між групами вірогідних відхилень вмісту вільних SH-груп встановлено не було.

Проводячи досліди по визначенню кількості вмісту білкових SH-груп у плазмі крові дослідних тварин було зафіксовано, що за згодовування кролям 3 і 4 дослідним групам вітамінно-мінеральної добавки «Tekro» у кількості 3,5 та 4,0\%, у цих тварин на 75 та 90 добу вірогідно підвищується, відносно контролю, вміст сірковмісної сполуки.

Одночасно, на 75 добу вирощування у печінці кролів 3 та 4 дослідних груп була визначена тенденція до підвищення вмісту білкових тіолових груп відносно показника у контролі.

Висновки. Використання гранульованого комбікорму з різним умістом досліджуваної вітамінно-мінеральної добавки позитивно вплинуло на перетравність поживних речовин корму у кролів новозеландської породи за інтенсивної технології вирощування. Оптимальною дозою вітамінно мінеральної добавки у складі раціонів для молодняку кролів новозеландської породи є 3,5\%.

\section{Список використаної літератури:}

1. Гуцол А.В., Сироватко К.М., Вугляр В.С. Використання білково-вітамінно-мінеральних добавок у тваринництві. Науковий вісник Львівського національного університету та біотехнологій імені С. 3 Гжицького. Сільськогосподарські науки. 2018. № 84. C. 154-160. DOI: 10.15421/nvlvet8428

2. Лавришин, Ю.Ю., Вархоляк І.С., Мартишук Т.В. Біологічне значення системи антиоксидантного захисту організму тварин. Науковий вісник Львівського національного університету та біотехнологій імені С. 3 Гжицького. Сільськогосподарські науки, 2016. №2, С. 100-111.

3. Козырь, В.С. Методика проведения балансовых опытов. Практические методики исследований в животноводстве. Д.: АРТ-Пресс. 2002. С. 79-91.

4. Козырь, В.С. Практические методики исследований в животноводстве. Д.: Арт-Пресс. 2002. С. 135-158.

5. Пабат, В.О., Вінничук Д.Т., Гончаренко І.В., Агій В.М. Кролівництво з основами генетики та розведення. К.: Ліра, 2018. $164 \mathrm{c}$.

6. Шалімов, М.О. Інноваційні технології виробництва і переробки продукції тваринництва. Одеса: ОДАУ, 2020.181 C.

7. Agoro, E. S., Akubugwo, E. I., Chinyere, G. C., and Ombor, A.J., 2017. Lipids levels in vitreous humor of rabbits after carbon monoxide poisoning death. SM Journal of Forensic Research and Criminololy, Vol. 1 (1), p. 1004-1008.

8. Al-Saghe, E.R., and Adham, A., 2019. Paulownia leaves as a new feed resource: Chemical composition and effects on growth, carcasses, digestibility, blood biochemistry, and intestinal bacterial populations of growing rabbits. Animals, Vol. 9, p. 95. DOI: 10.3390/ani9030095

9. Celia, C., Cullere, M., Gerencsér, Zs., Matics, Zs., Tasoniero, G., Dal Bosco, A., Giaccone, V., Szendrö, Zs., and Dalle Zotte, A., 2016. Effect of pre- and post-weaning dietary supplementation with Digestarom herbal formulation on rabbit carcass traits and meat quality. Meat Science, Vol. 118., p. 89-95. DOl: 10.1016/j.meatsci.2016.03.022

10. Dychok-Nedzelska, A.Z., Lesyk, Ya.V., and Kovalchuk, I.I., 2019. The effect of sulfur compounds on the content of microelements in tissue organism rabbits. Scientific Messenger of LNU of Veterinary Medicine and Biotechnologies. Veterinary Sciences. Vol. 21 (95), p. 161-165. DOl.org/10.32718/nvlvet9530

11. El-Aziz, A., El-Kasrawy, N., Abo Ghanima, M., Alsenosy, A., Raza, S., Khan, S., Menon, S., Khan, R., and Ullah, I., 2020. Influence of multi-enzyme preparation supplemented with sodium butyrate on growth performance blood profiles and economic benefit of growing rabbits. Journal of Animal Physiology and Animal Nutrition, Vol. 104, p. 186-195. DOI: 10.1111/jpn.13227.

12. Elwan, H., Abdelhakeam, M., El-Shafei, S., El-Rahman, A., Ismail, Z., Zanouny, A., Shaker, E., Al-Rejaie, S., Mohany, M., and Elnesr S., 2020. Efficacy of Dietary Supplementation with Capsicum Annum L on Performance, Hematology, Blood Biochemistry and Hepatic Antioxidant Status of Growing Rabbits. Animals, Vol. (10)11, p. 2045. DOI: 10.3390/ani10112045

13. Gugołek, A., Strychalski, J., and Kowalska, D., 2019. Growth performance and meat composition of rabbits fed diets supplemented with silkworm pupae meal. Spanish Journal of Agricultural Research, Vol. 17 (3), e0607, p. 9. DOI:10.5424/sjar/2019173-14882 
14. Hosny, N.S., Hashem, N., Morsy, A., and Alo-elezz, Z., 2020. Effects of Organic Selenium on the Physiological Response, Blood Metabolites, Redox Status, Semen Quality, and Fertility of Rabbit Bucks Kept Under Natural Heat Stress Conditions. Frontiers in Veterinary Science, 7:290. https://doi.org/10.3389/fvets.2020.00290

15. Ivanytska, A. I., Lesyk, Ya.V., Kropyvka, S.Y., and Hoivanovych, N.K., 2017. Growth and development of the organism rabbits for the feeding of the silicon connection. Scientific Messenger of Lviv National University of Veterinary Medicine and Biotechnologies. Vol. 19 (82), p. 82-87. DOl.org/ 10.15421/nvlvet8217.

16. Khan, K., Khan, S., Khan, R., Sultan, A., Khan, N., and Ahmad, N., 2016. Growth performance and meat quality of rabbits under different feeding regimes. Tropical Animal Health and Production, Vol. 48 (8). p. 1661-1666. D0I:10.1007/s11250-016$1140-4$

17. Kolawole, A. K., 2016. Effect of organic turmeric supplemented-diet in rabbits acutely exposed to ultraviolet radiation: oxidative stress in the blood. Anatomy \& Physiology: Current Research, Vol. 6 (4), p. 178-184. DOI: 10.4172/2161-0940.1000229

18. Lyasota, V.P., Bakhur, T.I., Utechenko, M.V., Fedorchenko, M.M., Rublenko, I.O., Bukalova, N.V., Bogatko, N.M., Antipov, A.A., Tkachuk, S.A., Prilipko, T.M., Sakhniuk, N.I., and Bogatko, A.F., 2020. Effect of a complex prebiotic preparation on the preservation, growth intensity and microflora in rabbits' intestine. Ukrainian Journal of Ecology, Vol.10 (6), p. 6-11, DOI: $10.15421 / 2020$ P.250

19. Read, T., Combes, S., Gidenne, T., and Destombes, N., 2016. Feed composition at the onset of feeding behaviour influences slaughter weight in rabbits. Livestock Science, Vol. 184, No 2. - P. 97-102. DOI: 10.1016/j.livsci.2015.12.015

20. Syvyk, T. L., Dyachenko L.S., Tytariova O.M., Shulko O.P., Osipenko O.P., Pirova L.V., and Bilkevych V.V., 2018. Productivity of rabbits and balance of selenium in their body by feeding different doses of selenium. Bulgarian Journal of Agricultural Science, Vol. 24 (3), p. 480-483.

21. Vizzarri, F., Chiapparini, S., Corino, C., Casamassima, D., Marisa Palazzo, M., Parkanyi, V., Ondruska, L., and Rossi, R., 2019. Dietary supplementation with natural extracts mixture: effects on reproductive performances, blood biochemical and antioxidant parameters in rabbit does. Annals of Animal Science, Vol. 20 (2), p. 565-578. DOl.org/10.2478/aoas-20190084

22. Yesmin, S., Uddin, M., and Chacrabati, R., 2013. Effect of methionine supplementation on the growth performance of rabbit. Bangladesh Journal of Animal Science, Vol. 42 (1). p. 40-43. DOI.org/10.3329/bjas.v42i1.15777

23. Zepeda-Bastida, A., Martinez, M.A., and Simental, S.S., 2019. Carcass and meat quality of rabbits fed Tithonia tubaeformis weed. Revista Brasileira de Zootecnia, 48:e20190074. DOl.org/10.1590/rbz4820190074

\section{References}

1. Hutsol, A.V., Syrovatko, K.M. and Vuhliar, V.S., 2018. Vykorystannia bilkovo-vitaminno-mineralnykh dobavok u tvarynnytstvi [The use of protein-vitamin-mineral supplements in animal husbandry]. Naukovyi visnyk Lvivskoho natsionalnoho universytetu ta biotekhnolohii imeni S. Z. Gzhytskoho. Silskohospodarski nauky, no. 84, pp. 154-160. DOI: 10.15421/nvlvet8428

2. Lavryshyn, Yu.lu., Varkholiak, I.S. and Martyshuk, T.V., 2016. Biolohichne znachennia systemy antyoksydantnoho zakhystu orhanizmu tvaryn [Biological significance of the antioxidant defense system of animals]. Naukovyi visnyk Lvivskoho natsionalnoho universytetu ta biotekhnolohii imeni S. Z. Gzhytskoho. Silskohospodarski nauky, no. 2, pp. 100-111

3. Kozyr. V.S., 2002. Metodika provedeniya balansovykh opytov. Prakticheskiye metodiki issledovaniy v zhivotnovodstve [Methods of conducting balance experiments. Practical research methods in animal husbandry]. D.: ART-Press.

4. Kozyr. V.S., 2002. Prakticheskiye metodiki issledovaniy v zhivotnovodstve [Practical research methods in animal husbandry]. D.: Art-Press.

5. Pabat, V.O., Vinnychuk, D.T., Honcharenko, I.V. and Ahii, V.M., 2018. Krolivnytstvo z osnovamy henetyky ta rozvedennia [Rabbit breeding with the basics of genetics and breeding]. K.: Lira.

6. Shalimov, M.O., 2020. Innovatsiini tekhnolohii vyrobnytstva i pererobky produktsii tvarynnytstva [Innovative technologies of production and processing of livestock products]. Odesa: ODAU.

7. Agoro, E. S., Akubugwo, E. I., Chinyere, G. C., and Ombor, A.J., 2017. Lipids levels in vitreous humor of rabbits after carbon monoxide poisoning death. SM Journal of Forensic Research and Criminololy, Vol. 1 (1), p. 1004-1008.

8. Al-Saghe, E.R., and Adham, A., 2019. Paulownia leaves as a new feed resource: Chemical composition and effects on growth, carcasses, digestibility, blood biochemistry, and intestinal bacterial populations of growing rabbits. Animals, Vol. 9 , p. 95. DOI: 10.3390/ani9030095

9. Celia, C., Cullere, M., Gerencsér , Zs., Matics , Zs., Tasoniero, G., Dal Bosco, A., Giaccone, V., Szendrő, Zs., and Dalle Zotte, A., 2016. Effect of pre- and post-weaning dietary supplementation with Digestarom herbal formulation on rabbit carcass traits and meat quality. Meat Science, Vol. 118., p. 89-95. DOI: 10.1016/j.meatsci.2016.03.022

10. Dychok-Nedzelska, A.Z., Lesyk, Ya.V., and Kovalchuk, I.I., 2019. The effect of sulfur compounds on the content of microelements in tissue organism rabbits. Scientific Messenger of LNU of Veterinary Medicine and Biotechnologies. Veterinary Sciences.

11. El-Aziz, A., El-Kasrawy, N., Abo Ghanima, M., Alsenosy, A., Raza, S., Khan, S., Menon, S., Khan, R., and Ullah, I., 2020. Influence of multi-enzyme preparation supplemented with sodium butyrate on growth performance blood profiles and economic benefit of growing rabbits. Journal of Animal Physiology and Animal Nutrition, Vol. 104, p. 186-195. DOl: 10.1111/jpn.13227. 
12. Elwan, H., Abdelhakeam, M., El-Shafei, S., El-Rahman, A., Ismail, Z., Zanouny, A., Shaker, E., Al-Rejaie, S., Mohany, M., and Elnesr S., 2020. Efficacy of Dietary Supplementation with Capsicum Annum L on Performance, Hematology, Blood Biochemistry and Hepatic Antioxidant Status of Growing Rabbits. Animals, Vol. (10)11, p. 2045. DOI: 10.3390/ani10112045

13. Gugołek, A., Strychalski, J., and Kowalska, D., 2019. Growth performance and meat composition of rabbits fed diets supplemented with silkworm pupae meal. Spanish Journal of Agricultural Research, Vol. 17 (3), e0607, p. 9. DOI:10.5424/sjar/2019173-14882

14. Hosny, N.S., Hashem, N., Morsy, A., and Alo-elezz, Z., 2020. Effects of Organic Selenium on the Physiological Response, Blood Metabolites, Redox Status, Semen Quality, and Fertility of Rabbit Bucks Kept Under Natural Heat Stress Conditions. Frontiers in Veterinary Science, 7:290. https://doi.org/10.3389/fvets.2020.00290

15. Ivanytska, A. I., Lesyk, Ya.V., Kropyvka, S.Y., and Hoivanovych, N.K., 2017. Growth and development of the organism rabbits for the feeding of the silicon connection. Scientific Messenger of Lviv National University of Veterinary Medicine and Biotechnologies, Vol. 19 (82), p. 82-87. DOl.org/ 10.15421/nvlvet8217.

16. Khan, K., Khan, S., Khan, R., Sultan, A., Khan, N., and Ahmad, N., 2016. Growth performance and meat quality of rabbits under different feeding regimes. Tropical Animal Health and Production, Vol. 48 (8). p. 1661-1666. DOI:10.1007/s11250016-1140-4

17. Kolawole, A. K., 2016. Effect of organic turmeric supplemented-diet in rabbits acutely exposed to ultraviolet radiation: oxidative stress in the blood. Anatomy \& Physiology: Current Research, Vol. 6 (4), p. 178-184. DOI: 10.4172/2161-0940.1000229

18. Lyasota, V.P., Bakhur, T.I., Utechenko, M.V., Fedorchenko, M.M., Rublenko, I.O., Bukalova, N.V., Bogatko, N.M., Antipov, A.A., Tkachuk, S.A., Prilipko, T.M., Sakhniuk, N.I., and Bogatko, A.F., 2020. Effect of a complex prebiotic preparation on the preservation, growth intensity and microflora in rabbits' intestine. Ukrainian Journal of Ecology, Vol.10 (6), p. 6-11, DOI: $10.15421 / 2020$ P.250

19. Read, T., Combes, S., Gidenne, T., and Destombes, N., 2016. Feed composition at the onset of feeding behaviour influences slaughter weight in rabbits. Livestock Science, Vol. 184, No 2. - P. 97-102. DOI: 10.1016/j.livsci.2015.12.015

20. Syvyk, T. L., Dyachenko L.S., Tytariova O.M., Shulko O.P., Osipenko O.P., Pirova L.V., and Bilkevych V.V., 2018. Productivity of rabbits and balance of selenium in their body by feeding different doses of selenium. Bulgarian Journal of Agricultural Science, Vol. 24 (3), p. 480-483.

21. Vizzarri, F., Chiapparini, S., Corino, C., Casamassima, D., Marisa Palazzo, M., Parkanyi, V., Ondruska, L., and Rossi, R., 2019. Dietary supplementation with natural extracts mixture: effects on reproductive performances, blood biochemical and antioxidant parameters in rabbit does. Annals of Animal Science, Vol. 20 (2), p. 565-578. DOl.org/10.2478/aoas-2019-0084

22. Yesmin, S., Uddin, M., and Chacrabati, R., 2013. Effect of methionine supplementation on the growth performance of rabbit. Bangladesh Journal of Animal Science, Vol. 42 (1). p. 40-43. DOl.org/10.3329/bjas.v42i1.15777

23. Zepeda-Bastida, A., Martinez, M.A., and Simental, S.S., 2019. Carcass and meat quality of rabbits fed Tithonia tubaeformis weed. Revista Brasileira de Zootecnia, 48:e20190074. DOI.org/10.1590/rbz4820190074

Fedorchenko Maxim Nikolaevich, assistant of the department of animal hygiene and basics of sanitation, Bila Tserkva National Agrarian University (Bila Tserkva, Ukraine)

Balance of mineral substances in the body of new zealand breed kings when feeding vitamin-mineral supplements

It is important to balance the diets of rabbits with minerals and vitamins. These compounds are very important for the body of rabbits and take an active part in metabolic processes. Animal health, reproduction, preservation and productivity depend on them. $A$ very important issue is the consumption of minerals by the animal, their assimilation in the body and excretion from it. The assimilation of mineral elements is influenced by security, their content in the feed, the nature of the compounds in which these elements are, the ratio between the individual mineral elements and their groups, vitamins, and so on. The author theoretically substantiated and practically proved the effectiveness of the use of vitamin and mineral supplement "Tekro" for rabbits of the New Zealand breed. According to the quantitative characteristics of the mineral elements required for animals, Calcium ranks first and is especially needed at the time of skeletal formation. The introduction into the diet of rabbits of the 3rd and 4th experimental groups of vitamin and mineral supplement "Tekro" showed increased absorption of calcium in their body. Thus, according to the indicator of assimilated Calcium, rabbits of the 3rd and 4th experimental groups predominated in control animals, respectively, by 4.1 and $7.8 \%$. $(p \leq 0.05)$. Phosphorus is also one of the main and very important trace elements and along with Calcium is involved in all metabolic processes in the body, being part of various organic compounds, proteins, phospholipids, nucleic acids. Additional feeding of vitamin and mineral supplements to experimental rabbits provided an increase in the rate of assimilated Phosphorus in the body of rabbits 2, 3- and 4th experimental groups, in which they exceeded control counterparts by $5.4 \%, 6.7 \%$ and $4.2 \%$. Feeding rabbits of New Zealand breed vitamin-mineral supplement "Tekro" in the amount of 3.5\% in the 3rd experimental group also helped to increase the intensity of their growth for 45 days, provided the opportunity for better transformation of nutrients from feed into products, which was confirmed by analysis of manometric parameters and recorded the highest percentage of slaughter yield at 90 days of age, which was $8.89 \%$ higher than the control group. Also in rabbits of the 3rd experimental group at the age of 90 days higher activity of glutathione peroxidase in blood plasma was observed, which was $11.2 \%(p \leq 0.05)$ higher in comparison with rabbits of the control group.

Key words: rabbits, vitamin and mineral supplement, balance experience, compound feed, minerals, calcium, phosphorus, massometric indicators.

Дата надходження до редакиії: 24.11.2020 p. 